\title{
The Native American Dream in Sherman Alexie's Short Story "One Good Man"
}

\author{
El Sueño Nativo Americano en el Cuento "One Good Man" de Sherman Alexie
}

MARÍA LAURA ARCE ÁlVAREZ

UNIVERSIDAD AUTÓNOMA DE MADRID

ORCID: https://orcid.org/0000-0003-2576-0295

ABSTRACT: The purpose of this article is to discuss the idea of the Indian identity and the Native American Dream in Sherman Alexie's short story "One Good Man." In this story, Alexie introduces the idea of the Indian constructed by the White Americans and attempts through his characters to redefine that concept by deconstructing all the different stereotypes created by the White American society. In order to do this, he also introduces the idea of the American Dream that he calls the "Native American Dream" to express the social inequality and hopeless existence of the Indian community always immersed in an ironic and comic discourse. In this sense, Alexie proposes a new definition of the Indian identity looking back to culture, tradition and the space of the reservation. He creates in his fiction a space of contestation and resistance opening a new voice for the Native American identity.

Key words: Sherman Alexie, Native American Literature, Postcolonial Literature, Postmodernism, US Studies, Literary Theory, Short Fiction.

RESUMEN: El objetivo de este artículo es analizar la idea de la identidad de los indios norteamericanos y el sueño nativo americano en el relato "One Good Man" del escritor Sherman Alexie. En esta historia, Alexie introduce la idea de la identidad indio norteamericana, pero construida por los blancos norteamericanos, e intenta a través de sus personajes redefinir este concepto deconstruyendo los distintos estereotipos creados por la sociedad norteamericana blanca. Para ello, también introduce la idea del sueño americano al que llama "el sueño nativo americano" con el fin de expresar la desigualdad social y la existencia desesperanzadora de la comunidad nativo americana, todo 
ello inmerso en un discurso irónico y cómico. En este sentido, Alexie propone una nueva definición de la identidad indio norteamericana volviendo a la cultura, la tradición y al espacio de la reserva. En su ficción, crea un espacio de contestación y resistencia dando lugar a una nueva voz para la identidad nativo americana.

Palabras clave: Sherman Alexie, Literatura Nativo Norteamericana, Literatura poscolonial, Posmoderinismo, Estudios de los Estados Unidos, Teoría literaria, Relato corto.

\section{INTRODUCTION}

Sherman Alexie is one of the most relevant Native American writers of the twentieth and twenty first centuries. In 2000, he published the collection of short stories The Toughest Indian in the World, stories that deal mainly with issues of Indian identity and the Native American experience. As the critic Stephen E. Evans states, Alexie's fiction always deals with characters conflicted by issues concerning their "indianness," that is, their racial, spiritual and cultural essence, and sexual and gendered identities (2010:186). All these aspects shape a possible answer for a question that haunts all his stories throughout the collection: "What is an Indian?" and that the author culminates in the last story with the title "One Good Man." Characters are always confronted with the difficulties to embrace and regain a sense of Indianness lost in their history and traditions. Concretely, characters face modern Indian attitudes and realities aware of the stereotypes that socially condemn them. Alexie's literary technique in this particular collection of short stories and especially in the short story "One Good Man" deconstructs, manipulates and therefore redefines all the American stereotypes of the Native American. In "One Good Man" Alexie reshapes the image projected to the Native American by the European Americans questioning what an Indian is and creates an answer for it using the stereotypes rooted in American society. Together with this, in his particular reformulation of the Indian identity, Alexie includes the concept of the Native American Dream as a fundamental aspect in the construction for a definition of the Native American of the twenty first century.

The collection of short stories The Toughest Indian in the World (2000) seems to go one step further beyond ethnicity and identity issues from the other collections of short stories. The title of this collection refers to a fragment of his first novel Reservation Blues (1996), in which the narrator explains the nostalgia and fear Native Americans feel once they leave the reservation, understanding it as a space of preservation: "Though they always pretended to be the toughest Indian men in the world, they suffered terrible bouts of homesickness as soon as they crossed the Spokane Indian Reservation border" (1995: 61). Also, the title itself remarks a male condition adopted by Indian men which forces them, as Daniel Grassian states, to "deny their vulnerability, their ability to think critically and to consciously decide on a more legitimate, individual identity" (2005:152). This is Alexie's starting point to construct his fiction and short stories based on race, sex and gender. Therefore, using this technique he discusses identity with the purpose of, as Grassian asserts: "criticize codes of male behavior and what he perceives to be the hegemonic patriarchal system of Indian and mainstream American male culture" (2005:158). Apart from this, Alexie still discusses certain topics that are recurrent in his 
other short stories and novels: the Indian identity and the space divided into the space of the reservation and the urban space as spaces that condition the identity in terms of contrast and interaction with the White-American society. In this context, Alexie constructs through an ironic and humoristic discourse an alternative Indian identity from his fictional space of resistance and contestation.

\section{THE INDIAN IMAGINARY SPACE}

\subsection{RELIGION}

The short story starts in the Spokane Indian Reservation with two Indian carpenters, Sweetwater and Wonder Horse, who are building a ramp for the wheelchair of the narrator's father. The Spokane Indian Reservation is a referential space for Alexie and pillar for his redefinition of the Indian identity. The narrator, as in other short stories, is Victor, a character repeated throughout Alexie's fiction. He describes them as two silent characters especially Sweetwater, who barely speaks to his work mate. However, Sweetwater decides to break his silence to remind his old friend that "Jesus was a carpenter" (2000: 209). The religious referent points to the colonial times and the means through which assimilation of the Native American population took place. In this sense, this is the first clash that Alexie introduces since this religious thought does not correspond to the essence of Indian spirituality. In fact, the break between the White colonizer's way of understanding the world and the Indian's is remarkable and unfixable. As Jennifer McClinton-Temple and Alan Velie explain in their Encyclopedia of American Indian Literature, the word "religion" does not exist for the Native Americans and assert that "In traditional Native American cultures spirituality is not a category or a limited expression of dualities such as good versus evil, spirit versus body, or sacred versus profane, but a belief system in which the world is a sacred place filled with wonder and awe" (2007: 342). Alexie's comparison between his character and Jesus opens an ironic discourse that makes possible the game with the Indian stereotypes and also introduces a discourse of regeneration, an alternative Indian world in which God can be Indian. Unavoidably, there is a connection between Jesus and the concept of good man that Wonder Horse breaks when he says to his friend in his discussion about the bible: "Now you sound like a Christian" (212) to what Sweetwater answers "Hey, that's dirty" (212). The concept of goodness linked to religion in this first part of the story and to American society excludes Native Americans from this moral reflection not only because of their supposed violent past but also because they represent, according to the stereotype, a constant threat to society. Paradoxically, this exclusion promoted by the White Americans stereotypes to Indians is also provoked by this spiritual fracture mentioned before, between White Americans and Indians. McClinton-Temple and Velie conclude in relation to spirituality:

This difference created a substantial divide between tribal consciousness and the consciousness of industrial or urbanized cultures driven by monotheism. One system promotes wholeness, while the other is based on division and separation. One system promotes a circular, unified field of interaction, while the other is linear and sequential.

(2007: 343)

Although the Indian vision of the world implies a sense of union and circularity, they live condemned to the rupture introduced by the urbanized world. Only this can be solved in the space of the reservation, fundamental for the reconstruction and preservation of the Indian tradition and culture basic in Alexie's fiction. 


\subsection{THE RESERVATION}

For Alexie's definition of Indian, space becomes a fundamental aspect to be taken into account. According to MacLeitch "most Indians, however, resisted racialized definitions of identity, preferring to define their Indian status by means of such cultural markers such as dress, economic behavior, shared folklore beliefs and religious rites. Many saw the communal ownership of land as central to their construction of Indianness" (2006:111). However, in order to convey a postmodern definition of the Indian identity and concretely to the word Indian, it is essential to consider space and time together. As Mishuana R. Goeman expresses it "much of what constitutes being an Indian in popular culture which filters itself into colonial logics and management on the ground stems from historical images of savages" (2014: 236) that are intimately related to places and bodies that "are marked and unmarked in ways that make them legible or illegible as Indigenous people" (2014: 236). The colonial discourse has marked many aspects in the lives of Native American people and concretely space as a fundamental issue to define what an Indian is. In this context, Goeman explains that "Native people living on occupied land is not only physical occupation of land that has occurred but also our material, symbolic, and lived spaces from the body to the home and to the nation" (2014: 237) so the representation of the Native Americans is conditioned by the colonial occupation as an usurpation not only of their lands but also of their bodies. Indeed, Goeman asserts that "Whereas Indians can exist in space, as in the space of the Wild West in the 1800s, it is much harder to place Indians" (2014: 239). Thus, placing Indians in the context of the America of the twentieth and the twenty first centuries becomes a complex task since they seem to fluctuate from the space of the reservation, as it occurs in Alexie's fiction, to the urban space of the cities as a threat for their culture and tradition. In the concrete case of the short story analyzed here, Alexie's characters fluctuate from the reservation to the city and the American institutions. In his fiction, the reservation is a place hit by internal colonization and therefore it projects the economic, social, cultural and geographical problems suffered by the Indians. On the one hand, the reservation is a mirror of Indian degradation and cultural extermination on the other, a place of resistance fundamental to answer the question "What is an Indian?"

I left the reservation for the same reason a white kid leaves the cornfields of Iowa, or the coal mines of Pennsylvania, or the oil derricks of Texas: ambition. And I stayed away for the same reasons the white kids stayed away: more ambition. Don't get me wrong. I loved the reservation when I was a child and I suppose I love it now as an adult (I live only sixty-five miles away), but it's certainly a different sort of love. As an adult, I am fully conscious of the reservation's weaknesses, its inherent limitations (geographic, social, economic, and spiritual), but as a child I'd believed the reservation to be an endless, magical place.

(2000: 221)

Some lines after, the narrator reflects about the question "What is an Indian?" by wondering: "Is it the lead actor in a miracle or the witness who remembers the miracle?" (2000: 221). The question can be interpreted as a reference to the survival of the Native American community and the future generations like him. The narrator describes the reservation as a "magical place," in his experience as a child, and afterwards as a place of poverty in his adulthood. As the fragment quoted above shows, even though "the reservations in most cases fail to offer few educational or economic opportunities" and "urban relocation poses a whole range of new problems: racial discrimination, cultural dislocation, and alienation" (McClinton-Temple \& Vile, 2007: 299), Alexie is able to 
recreate and recover the magical and even supernatural aspects that the reservation can have as a "magical place" where miracles like survival occur. Mainly, the supernatural powers of the reservations refer to preservation since "the reservations also represent a world in which Indians have maintained a cultural and geographical identity. For better or worse, many reservations are regions distinct from mainstream America" (McClintonTemple \& Vile, 2007: 299). In relation to this, the critic Wendy Belcher interprets magic in Alexie's fiction as a metaphor related to white power and white oppression. This transgression is depicted for Alexie in the space of the reservation since in itself, the reservation represents white domination (2007: 31). In the context of Belcher's thesis, the narrator as a child experiences the reservation as a magical place since he feels in the reservation the fake freedom and recognition given by colonialism. However, the reservation turns into a jail as he grows up, a limited space where the American Dream cannot be accomplished. For this reason, the protagonist leaves the reservation to find a better life: "I left the reservation for the same reason a white kid leaves the cornfields of Iowa, or the coal mines of Pennsylvania, or the oil derricks of Texas: ambition" (Alexie, 2000: 221). As Margaret J. Downes claims, the American Dream is intricately related to space: "Part of the American Dream is the Frontier Dream, the dream of being a strong individual who can get past all the fences of convention and tradition and can make it alone" (2009: 130). Here, the protagonist, as Downes points out, is trying to surpass the limits the reservation imposes him, which at the same time represent convention and tradition symbolically. As any American, he is looking for the American dream, but this dream is false since he has been seduced by the illusory recognition experienced in the reservation. Certainly, at the end he admits that: "As an adult, I am fully conscious of the reservation's weaknesses, its inherent limitations (geographic, social, economic, and spiritual) (Alexie, 2000: 221), but still with certain nostalgia for a place that has distorted his memories and, above all, his cultural identity.

In terms of the "inherent limitations" of the reservation, it is remarkable how the narrator points out to the political aspects that delimit race and therefore the identity of the Indian. Bearing in mind that the reservation is a manifestation of the white colonial power, the different social, economic and especially geographic and spiritual obstacles it presents are decisive in the definition of the Indian. Again, the idea of race and racism, claimed also by the critic Gerald Vizenor (1995), turns up as the main border to cross inside the reservation. Homi Bhabha in his work The Location of Culture (1994) explains how the colonial discourse works and where the individual is located in it:

It is an apparatus that turns on the recognition and disavowal of racial/cultural/historical differences. Its predominant strategic function is the creation of a space for a 'subject peoples' through the production of knowledges in terms of which surveillance is exercised and a complex form of pleasure/unpleasure is incited. It seeks authorization for its strategies by the production of knowledges of colonizer and colonized which are stereotypical but antithetically evaluated. The objective of colonial discourse is to construe the colonized as a population of degenerate types on the basis of racial origin, in order to justify conquest and to establish systems of administration and instruction.

(1998: 70)

Bhabha defines the colonial discourse as a racial system that locates the 'subject peoples' in spaces created by them in order to recognize and reject the cultural values of the other. In this way, as he asserts, the colonial discourse reinforces its domination and establishes its "systems of administration and instruction." In this context, the reservation turns into that space of oppression that the narrator identifies with magic as a way to symbolize the western domination. Bhabha proposes the creation of a "in between space" where the displaced individual can, in a context of oppression, create a space for herself 
or himself, especially in cultural terms. Bhabha concludes: "These 'in-between' spaces provide the terrain for elaborating strategies of selfhood-singular or communal-that initiate new signs of identity, and innovative sites of collaboration, and contestation, in the act of defining the idea of society itself" (1998: 1-2). It is in this space where Alexie constructs his particular definition of "what is an Indian?"

Paradoxically, Alexie introduces the idea of "miracle" in order to present the figure of the Indian as the protagonist and witness of an extraordinary event since he is the survivor of a terrible genocide. The narrator states:

Though I didn't see my siblings much, perhaps two or three times a year at family and tribal gatherings, we'd always been happy to see one another and had easily fallen back into our comfortable patterns: hugs, kisses, genial insults, then the stories about our mother, and finally the all-night games of Scrabble. None of us had ever found the need to chastise any of the others for our long absences from each other. We'd all pursued our very different versions of the American Dream (the Native American Dream!) and had all been successful to one degree or another. We were teacher, truck driver, logger, accountant, preacher, and guitar player. Our biggest success: we were all alive. Our biggest claim to fame: we were all sober.

(2000: 219)

As it is evident, Alexie points out two aspects associated with the Indian community: survival and alcoholism; one as a success and the other as the immediate social and cultural consequence of their repression. Drinking is a terrible problem in the Native American community and in reservations, but also it is a distinguishing sign of the Native American Dream in relation to the American Dream. As Downes affirms, while alcohol can be "an illusion of participating in the American Dream," alcohol consumption in the Native American world becomes a sign of devastation (2009: 128-129). In this particular case, alcoholism becomes an obstacle to reach the Native American Dream that is very limited in comparison to the American. Instead of aspiring to wealth, their only expectations are existence and sobriety. Indeed, he also mentions ordinary professions as a claim of success: teacher, truck driver, logger, accountant, preacher or guitar player; some of them very distanced from the traditional American Dream. Thus, it is just the destruction of these stereotypes what can take them to fame, as he says, and unmask the real image of the Native.

\subsection{The NATIVE AMERICAN Dream}

In this context, it is possible to establish a connection between this vision of identity and what Alexie calls the "Native American Dream." As Cullen defines, the American Dream is a fundamental part of the American national identity for the following reasons:

The United States was essentially a creation of the collective imagination-inspired by the existence of a purportedly New World, realized in a Revolution that began with an explicitly articulated Declaration, and consolidated in the writing of a durable Constitution. And it is a nation that has been re-created as a deliberate act of conscious choice every time a person has landed on these shores. Explicit allegiance, not involuntary inheritance, is the theoretical basis of American identity.

In this recapitulation of the different steps in the formation of the American identity, Cullen emphasizes the loyal nature of this condition, more than the "involuntary inheritance" in which, according to White Europeans, Native Americans would be included. The "explicit allegiance" justifies the illegal appropriation of the land and 
therefore, the construction of an identity linked to that land. In this context, the Native Americans belong to that uncertainty described by Cullen in the construction of an American national identity and try to pursue their American Dream. According to Margaret J. Downes the Native American Dream is a dream of belonging, a complicated quest in which they only find real happiness with their family and in the reservation (2009: 123). Indeed, she asserts: "their sense of self and spirituality, comes from their identification with their cultural group, especially their families; it's in that group that they find a dream fulfilled as much as any dream can be fulfilled" (2009: 124). However, Alexie's characters do not experience a dream of belonging but show a "Native American Dream" based on the destruction of bonds, of the spirituality and the poverty of the reservation. Thus, Alexie's "Native American Dream" becomes a "Native American Nightmare" in which Indians desperately try to escape from total extermination. According to Philip J. Deloria this experience of the "Native American Nightmare" is intimately linked with Indian identity: "while Indian people have lived out a collection of historical nightmares in the material world, they have also haunted a long night of American dreams. As many native people have observed, to be American is to be unfinished. And although that state is powerful and creative, it carries with it nightmares all its own" (1998: 191). Undoubtedly, Alexie's characters find a sense of Indian identity in their ancestors, family and in the reservation but it is very hard for them to find this essence. In other words, Alexie's characters existential quest is based on finding the Indianness in a Native world almost destroyed and corrupted by the White-Americans exterminating actions. So, Alexie's picture of the Native American Dream is one of poverty, extermination and hopelessness.

\section{INDIAN IDENTITY}

\subsection{WHAT IS AN INDIAN?}

The attempt to define "Indian" is divided in two different sections in the story. First of all, the narrator attempts to give his own definition of Indian by connecting it with the family and the space. The narrator constantly presents him as a son and how he places himself in relation to his dying father. The figure of the father, a sick old Indian destroyed by his diabetes, becomes an illustrative metaphor for the deterioration and damage caused to the Indian community. In different occasions his role as son seems to contribute to answer the question: "What is an Indian? Is it a son who can stand in a doorway and watch his father sleep?" (2000: 222); "What is an Indian? Is it a son who brings his father to school as show-and-tell?" (2000: 227); "What is an Indian? Is it a son who had always known where his father kept his clothes in neat military stacks?" (2000: 230). He carries the burden of all the stereotypes consequence of the damage provoked by the action of the White man. Mainly, the father stands for the idea of tradition that, as he is described in the text, it is in a critical situation. As the narrator constantly answers the question with another one referred to "a son," this anonymous son becomes the legacy of a dying tradition that hardly survives beyond the frontiers of the reservation. The protagonist also places himself in the role of father, as a continuation of the indigenous identity and as the following fragment shows, participant of this Indian tradition which is explicitly on the verge of assimilation:

I was happy that my son was living in Seattle, where twenty percent of the city was brownskinned, instead of Spokane, where ninety-nine percent of the people were white. I'm not exactly racist. I like white people as a theory; I'm just not crazy about them in practice. But, all in all, ours was a good divorce. I still loved my ex-wife, without missing her or our marriage (I'm a liar), and spent every other weekend, all of the major holidays, and 
most of the minor ones, with the three of them in Seattle-all of us having decided to make it work, as the therapist had said. The nontraditional arrangement, this extended family, was strange when measured by white standards, but was very traditional by Indian standards. What is an Indian? Is it a child who can stroll unannounced through the front doors of seventeen different houses?

(2000: 217)

Through the narrator's voice Alexie describes the fragmentation and break of the family union, so important for the Native communities and especially the assimilation provoked by the migration of Indians to the city. The narrator, in his role as father, has a family "measured by white standards" showing the clash between the Indian and the White worlds, and therefore the unfixable fissure that exists between them. According to Sean Kicummah Teuron "those activities viewed as assimilation in the early twentieth century-such as moving to the city, attending college, wearing a suit, or traveling through Europe-may also be viewed as forms of resistance to a dominant culture that has said that Indigenous people cannot do such things" (2014: 320). In relation to this, Chris Andersen asserts that "authorities assumed that the movement of Indigenous individuals and families to urban space was synonymous with our assimilation, in particular, our loss of identification with whatever Indigenous affiliation we previously claimed" (2015:162) implying that the movement of certain Native individuals to the modern cities was a threat to the culture and tradition of Indigenous people who will progressively be absorbed by the life of the modern city. Nevertheless, as Andersen explains "not only did we not lose our identities as Indigenous people, we began to produce new forms of Indigenous identity and culture distinctive not only to urban life in general but even to particular cities" (2015: 162). Alexie plays with this confrontation of White and Indian worlds in the sense that his characters move from the reservation to the city in order to experience the life of the modern city, the life in the American institutions and face assimilation as a way of deconstructing the rooted stereotypes in White American society. Also, as a way of trying to experience the American Dream. Thus, Andersen concludes, "urban indigenous landscapes have belied dominant, stereotypical thinking both about where Indigenous peoples really belong and the logical endpoint of urban migration-extinction" (2015: 162). From Goeman's perspective, Alexie tries to place Indians in the American world as opposed to the American colonial discourse that has been trying to do it for centuries.

In an attempt to respond to this colonial definition of the word Indian, the critic and writer Gerald Vizenor claims that this word "is a convenient word, to be sure, but is an invented name that does not come from any native language, and does not describe or contain any aspects of traditional tribal experience and literature" (1995: 1). Essentially, Vizenor points to the colonial nature of the concept in the sense that it is a word imposed by the White colonizers in their attempt to describe the Native people. In this sense, Vizenor claims for a cultural break in the definition of the word and therefore, a reformulation of the concept: "Indian is a simulation of racialism, an undesirable separation of race in the political and cultural interests of discovery and colonial settlement of new nations, the noun does not reveal the experiences of diverse native communities" (1995: 1). In the same line of thought, Gail D. MacLeitch explains how the concept of Indian identity is conceived from a "racialized perception, which encouraged a static view of Indians as primitive, trapped in the past, unwilling or unable to change and therefore on the verge of extinction" (2006: 113). However, in his analysis, Indian identity stands as a "fixed immutable category" (2006: 113) that was refuted by reformers who tried to assimilate Native people through Christian conversion and in this sense "Indianness was a temporary state of existence that needed to be overcome" (2006: 113). 
However, this dichotomy exposed by MacLeith that left Native people on the verge of extinction on the one hand but also with the possibility of overcoming their Indiannes and therefore assimilation on the other is used by the critic Philip Deloria to explain the essence for a definition of Indian identity. He claims that American policy towards Indians has been a constant game of acceptance and extermination and:

The indeterminacy of American identities stems, in part, from the nation's inability to deal with Indian people. Americans wanted to feel a natural affinity with the continent, and it was Indians who could teach them such aboriginal closeness. Yet, in order to control the landscape, they had to destroy the original inhabitants.

(1998: 5)

This colonial impression of the Indian is what according to Kevin Bruyneel still persists in the discussion of the definition for an Indian identity and tribal sovereignty at the turn of the twenty first century. Bruyneel explains how there has been an inversion of the colonial discourse in which the Indigenous tribes have become the colonizers and the American nation the colonized (2007:171). From this perspective, the formation of a collective identity takes place from the domination of another group "in material, cultural and political terms" (2007:8):

Such a dominant group forms the boundaries of its own internal identification by, in great part, establishing what the group is not via the construction of a "constitutive outside" that represents the other half of couplings such as self-other, citizen-alien, sovereign subject (s)-dominated object (s), and civilized-savage.

Bruyneel concludes that in this attempt to define a national and collective identity the "settler-state" sovereignty is legitimate whereas the "indigenous' people" sovereignty is illegitimate since "the former is progressive and civil and the latter is archaic and savage" (2007:8). Thus, the national narrative of the turn of the twenty-first century in America is still based on a "civilization-savagery" opposition that conditions not only the definition of Indian identity but also the limits of their space in American society. Bruyneel's definition of the third space for indigenous people is "an effort to provide a straightforward claim about what it means for a people to seek and express control of their lives, free from colonial domination" (2007:23). Evidently, Bruyneel takes his idea of the "third space of sovereignty" from Bhabha's concept of the third space but as he explains, his third space of sovereignty represents "supplementary strategy" that "does not turn contradiction into dialectical process. It interrogates its object by initially withholding its objective" (2007:21).

\subsection{THE INDIAN STEREOTYPE}

But probably, one of the central parts of the story is the protagonist's college experience with Dr. Lawrence Crowell, a professor at Washington State University. Here is where Alexie discusses directly the Indian stereotypes and what the critic Louis Owen calls the mirror game in the construction of an American identity in detriment of an Indian one (2001: 17). In this constant dialogue between White Americans and Native Americans to construct both identities, the Indian identity has always been based on stereotypes imposed by the White Americans. As Bhabha asserts "the visibility of the $\mathrm{racial} /$ colonial Other is at once a point of identity ("Look, a Negro") and at the same time a problem for the attempted closure within discourse" (1998: 81). Alexie's fiction shows the confrontation his characters suffer with these stereotypes created for the Native Americans in a dynamic of opposition that constantly shows what the White Americans 
are not. In this context, Alexie's fiction depicts the clash between White and Indian worlds in a society that has been constructed in the awareness of the existence of the Native American community. Owens explains the construction of the European American identity as a mirror game in which the European Americans necessarily turn toward the Native Americans:

European America holds a mirror and a mask up to the Native American. The tricky mirror is that Other presence that reflects the Euro-American consciousness back at itself, but the side of the mirror turned toward the Native is transparent, letting the Native see not his or her own reflection but the face of the Euro-American beyond the mirror

(2001: 17)

The transparent side of the mirror reflects the image the European America has created of the Native Americans, the stereotype that conditions the Native American existence and, in many occasions, defines it as a constant fight to deconstruct them. Some lines after, Owens concludes: "In order to be recognized, and to thus have a voice that is heard by those in control of power, the Native must step into that mask and be the Indian constructed by white America" (2001: 17). From this perspective, this mask is for the Native Americans both a tool necessary to be visible; it is "a point of identity" (1998: 81), and a false and Europeanized reflection of themselves and their existences. Nevertheless, as Owens states, this mask is a symbol to be recognized and allows them to be heard. In this line of thought, Philip J. Deloria understands the symbol of the mask as a way of making "one self-conscious of a real "me" underneath" (1998: 7). Thus, the mask, as the metaphor for an imposed image by the White Americans, as a metaphor for the stereotype that conditions Native American identity, can be also considered a tool of resistance and contestation through which the Native American deconstructs the stereotype imposed by society. In his constant confrontation with the American society, Alexie's fiction attempts to destroy the stereotype in order to construct an Indian identity. In this sense, the stereotype becomes a tool of resistance in a society that constantly tries to make them invisible. Certainly, Owens affirms that "the mask merely shows the Euro-American to himself, since the masked Indian arises out of the European consciousness, leaving the Native behind the mask unseen, unrecognized for himself or herself' (2001: 17), nevertheless, if we consider the mask as a tool of resistance and a symbolic space where the Indian hides his or her real self, the Indian identity would be always present in the dialogue that reaffirms American identity. In other words, even though it is hidden, the White American will be always looking at the hidden Native every time he or she wants to identify in that mirror and therefore the Native American, despite the difficulties of recognizing himself or herself, would have the opportunity to emerge. In this context, Alexie's characters could be interpreted as those existing behind the mask, those hidden behind the reflection showed by "the Euro American to himself" (2001: 17).

The experience he has at college seems to illustrate Owen's words as he, as an Indian, sees a reflection of himself that is the construction the Euro-Americans have done of him and his Indian peers. The character that Alexie chooses to describe this is "according to his vita, a Cherokee-Choctaw-Seminole-Irish-Russian Indian from Hot Springs, Kentucky, or some such place" (2000: 224) who writes on the board the key question "What is an Indian?" The professor asks directly the protagonist due to his evident physical appearance. From "What is an Indian?" he changes to "Are you Indian?" and after several questions related to his Native identity and specially to check if he was a full-blood Indian, the protagonist answers "You know," I added. "My momma always used to tell me, those mixed-blood Indians, they just ain't sexy enough" (2000: 225). The narrator is expelled from the classroom. Again, using the irony and humor characteristic of Alexie's texts, Dr. Crowell responds to the mirror game proposed by Owen as the 
narrator explains: "Of course, my mother would have felt only contempt for a man like Dr. Lawrence Crowell, not because he was a white man who wanted to be an Indian (God! When it came right down to it, Indian was the right thing to be!), but because he thought he was entitled to tell other Indians what it meant to be an Indian" (2000: 227). This episode provokes the coming of the narrator's father to the class. The professor, surprised, tries to ignore him but he is there in order to answer his obsessive and repetitive question. The two characters begin an argument right in front of all the college students, the professor trying to prove that he is more Indian than the father; the father trying to show him that he is just a human being like any other. In the discussion, he claims:

"I don't know," said my father. "Now, you may have some Indian blood. I can see a little bit of that aboriginal bone structure in your face, but you ain't Indian. No. You might even hang out with some Indians. Maybe even get a little of the ha-ha when one of the women is feeling sorry for you. But you ain't Indian. No. You might be a Native American but you sure as hell ain't Indian."

(2000: 228)

If we understand the father's words in the light of the above mentioned Vizenor's definition of Indian, he is reclaiming the "traditional tribal experience and literature" that Vizenor points out as fundamental to describe the condition of Indian. The professor attacks the father with a revolutionary argument:

"What about Wounded Knee?" Crowell asked my father. "I was at Wounded Knee. Where were you?"

"I was teaching my son here how to ride his bike. Took forever. And when he finally did it, man, I cried like a baby, I was so proud."

"What kind of Indian are you?" You weren't part of the revolution."

"I am a man who keeps promises."

It was mostly true. My father had kept most of his promises, or had tried to keep all of his promises, except this one: he never stopped eating sugar.

(2000: 229)

Alexie depicts an Indian whose revolutionary side is in the everyday life, in the survival, in the preservation of customs and above all, in his humanity. His revolution is in teaching his son how to ride his bike. On the other hand, the professor represents in Alexie's fiction the obsession for a definition of Indian that can include him. This episode in Alexie's short story shows Owens's other side of the mirror, that in which the Native is hidden but the White American needs to see in order to construct his own identity. Evidently, in his Indian mask, in his desperation to impersonate Indianness, the professor is obsessively trying to construct his identity. However, the protagonist leaves a sad message in this episode when he concludes that his father, as a diabetic, always kept his promises except one "he never stopped eating sugar" (2000: 229). Here, the idea of autodestruction is evident and consequently the incurable wound left in the Native community by the past harmful experiences. This idea is related to Ward Churchill's thesis about "demoralization" when he talks about some of the consequences extermination left in the Indians: "entire people, having "lost the will to live" in the face of the sudden dispossession of both their homeland and their way of life as well as most of their friends and relatives (1998: 151)." Alexie's illustration of Churchill's idea of "demoralization" is expressed through the character's self-annihilation and evidences the persistence of the colonial genocidal project. It is, as Churchill concludes, a story of dispossession and a permanent wound in the future of the Indian community. 


\section{CONCLUSION}

Alexie finishes the short story going back to the idea of religion and the original idea of God giving the story a cyclical tone. And of course, it finishes with the last question of "What is an Indian?" but this time is not answered with another question but with a statement: "I lifted my father and carried him across every border" (2000: 238) as a way of revendicating the survival of the Indian history, tradition and culture beyond the walls of the reservation and the system in order to reverberate in American history. Alexie concludes his definition of Indian in this short story as a total deconstruction of the stereotypes created by the White Americans and inventing a heterogeneous world and space for the Native Americans. At the same time, in his redefinition of the Indian identity, he illustrates the confrontation of White and Indian worlds but also shows the contradictory dialogue that seems to have survived since the time of colonization in which the White Americans chose extermination but realized they needed the presence of the Indians in order to imagine and materialize an American identity. In relation to this, he uses the line What is an Indian? as a chorus, a question always answered with another question which refers to a preconceived Indian stereotype. Through the patchwork of stories, Alexie deconstructs the stereotype but constructs an ordinary, traditional and more human "history" for the Indian. He presents the concept of "traditional tribal experience and literature" that Vizenor refers to. Thus, the question What is an Indian? is open to interpretation, maybe answered not only by one statement but the whole imaginary world of Alexie's fiction.

\section{WORKS CITED}

Alexie, S. 1995. Reservation Blues. New York: Warner Books.

Alexie, S. 2000. The Toughest Indian in the World. New York: Grove Press.

Andersen, C. 2015. "Urban Landscapes of North America". In Warrior (ed.), The World of Indigenous North America. New York: Taylor \& Francis, 149-172.

Bataille, G. 2001. Native American Representations: First Encounters, Distorted Images, and Literary Appropiations. Lincoln: University of Nebraska Press.

Belcher, W. 2007. "Conjuring the Colonizer: Alternative Readings of Magic Realism in Sherman Alexie's Reservation Blues". American Indian Culture and Research Journal, 31:2, 87-101.

Bhabha, H. 1998. The Location of Culture. New York: Routledge.

Bloom, H. 2009. The American Dream. New York: Chelsea House.

Bruyneel, K. 2007. Third Space of Sovereignty: The Postcolonial Politics of U.SIndigenous Relations. Minnesota: University of Minnesota Press.

Churchill, W. 1997. A Little Matter of Genocide: Holocaust and Denial in the Americas 1492 to the Present. San Francisco: City Light Books.

Cox, J. \& Heath Justice, D. (eds.). 2014. The Oxford Handbook of Indigenous American Literature. Oxford: Oxford University Press.

Cullen, J. 2003. The American Dream. New York: Oxford University Press.

Deloria, P. 1998. Playing Indian. New Heaven: Yale University Press.

Downes, M. 2009. "Love Medicine and the American Dream”. In H. Bloom (ed.), The American Dream. New York: Chelsea House.

Evans, Stephen F. 2010. "Sex/Gender Variability, Indianness and Intimacy in Sherman Alexie's The Toughest Indian in the World". In J. Berglund \& J. Roush, Sherman Alexie: A Collection of Critical Essays. Utah: University of Utah Press, 186-211.

Goeman, M. 2014. "Disrupting a Settler-Colonial Grammar of Place: The Visual 
Memoir of Hulleah Tsinhnahjinnie”. In A. Simpson \& A. Smith (eds.), Theorizing Native Studies. Durham: Duke University Press, 235-296.

Grassian, D. 2005. Understanding Sherman Alexie. Columbia, South Carolina: University of South Carolina Press.

McClinton-Temple, J. \& Velie. A. (eds.). 2007. Encyclopedia of American Indian Literature. New York: Facts On File.

MacLeitch, G. 2006. Native Americans. A New Introduction to American Studies. In H. Temperley \& C. Bigsby (eds.). Harlow: Pearson Longman.

Simpson A. \& Smith A. (eds.). 2014. Theorizing Native Studies. Durham: Duke University Press, 98-122.

Temperley, Howard \& Christopher Bigsby (eds).2006. A New Introduction to American Studies. Harlow: Pearson Longman.

Teuton Kicummah, S. 2014. "The Indigenous Novel”. In J. Cox \& D. Heath Justice (eds.), The Oxford Handbook of Indigenous American Literature. Oxford: Oxford University Press, 318-332.

Owens Louis. 2001. "As if an Indian Were Really an Indian: Native American Voices and Postcolonial Theory". In G. Bataille (ed.), Native American Representations: First Encounters, Distorted Images, and Literary Appropiations. Lincoln: University of Nebraska Press, 11-25.

Vizenor, G. 1995. Native American Literature. California: Longman.

Warrior, R. 2015. The World of Indigenous North America. New York: Taylor and Francis. 